\title{
Mergers and acquisitions: types, principles, historical information and empirical evidence from the Greek banking sector
}

\author{
Rompotis, Gerasimos G.
}

- ReCeIved: 22 january 2014

- ACCePted: 10 JUNe 2014

\begin{abstract}
This paper describes the types and main principles of mergers and acquisitions, a strategic policy adopted by many firms worldwide in their efforts to expand their business, enter new markets, sectors and countries as well as to mitigate the competition they face from rivals. In addition to the description of the various types of mergers and acquisitions, the motivations behind such actions are broken down along with the obstacles and counterincentives that can lead to the failure of such deals and the significant issue of financing a merger or an acquisition. A brief analysis of the recent trends in international mergers and acquisitions is subsequently provided. The paper goes on to focus on the recent wave of acquisitions in the Greek banking sector by highlighting the case of Alpha Bank's takeover of Emporiki Bank. The analysis performed provides some evidence of a positive financial effect for Alpha Bank's shareholders as a result of the announcement of that takeover.
\end{abstract}

\section{Keywords:}

Mergers, Acquisitions, Banking sector, Greece.

JEL classification:

G34. 


\section{Fusiones y adquisiciones: tipos, principios, información histórica y evidencia empírica del sector bancario griego}

Rompotis, Gerasimos G.

\section{Resumen}

Este artículo describe los tipos y principios fundamentales de las fusiones y adquisiciones, política estratégica adoptada por muchas compañías de todo el mundo en su esfuerzo por expandir su negocio, entrar en nuevos mercados, sectores y países, así como por mitigar la competencia de otros rivales. Además de la descripción de los diferentes tipos de fusiones y adquisiciones, se desglosan las motivaciones que subyacen a tales acciones, junto con los obstáculos y contra-incentivos que pudieran hacer fracasar tales acuerdos, así como se estudia la importante cuestión de su financiación. A continuación, se lleva a cabo un breve análisis de las tendencias actuales en el curso de las fusiones y adquisiciones. Posteriormente, el artículo se centra en la ola de recientes adquisiciones en el sector bancario griego, destacando el caso de la absorción del Emporiki Bank por el Alpha Bank. El análisis realizado proporciona cierta evidencia del efecto positivo en el valor de la cartera de los de los accionistas del Alpha Bank provocado por el anuncio de tal absorción.

\section{Palabras clave:}

Fusiones, adquisiciones, sector bancario, Grecia. 


\section{Introduction}

The globalization of the economy, the liberation and consequent spectacular growth in the international trade of goods and services as well as the free movement of capital has led to fierce competition in every single sector of the global business field. As a result, companies must continuously strive to increase their size and market shares, upgrade their knowledge, improve their effectiveness and performance, and optimize the usage of all the available resources so as to ensure their survival and success.

In pursuing growth, companies have three main alternative possibilities to choose from. The first concerns internal growth where the company builds on its own capabilities investing capital in developing new products, markets, skills and knowledge. The second choice relates to the so-called "strategic alliances" such as joint ventures, franchises and network co-operation. The third possibility, and in fact a common course of action, regards the mergers and acquisitions of entities that may operate in similar business sectors (horizontal integration) or different sectors (vertical integration).

The phrase "mergers and acquisitions" (M\&A) relates to the corporate strategy, corporate finance and business management involved with the buying, selling, dividing and combining of different or similar entities with a view to helping an enterprise grow rapidly and boost its position in its sector or location of origin. Mergers and acquisitions also allow companies to enter a new field or new location or country without the need to create a subsidiary entity or use a joint venture.

The distinction between a merger and an acquisition has become increasingly blurred in various aspects. Although the terms merger and acquisition are often used synonymously, they mean slightly different things. When one company takes over a part or the whole of another and clearly establishes itself as the new owner of the entity, the transaction is regarded as an acquisition. From a legal point of view, in the case of the total acquisition of a company, the result of such a transaction is that the buyer absorbs the business and the target company ceases to exist. In addition, in the case of listed companies, only the stocks of the buyer company continue to be traded on the stock exchange. In the case of partial acquisitions, the buyer may or may not take over the management and control of the target company depending on the portion of the entity acquired and the portion remaining in the hands of the previous shareholders. It should be added that, usually, the companies involved in an acquisition are of different magnitudes, meaning that a large company purchases a smaller one.

On the other hand, a merger happens when two firms reach an agreement to continue their business action as a single new company instead of remaining separately owned and operating individually. This kind of action is more precisely referred to as a "merger 
of equals". The entities involved in a merger of this kind are often of about the same size. In addition, the stocks of both companies are redeemed and new stock is issued to replace the old one. As an additional distinction between mergers and acquisitions, we should note that a purchase deal is also called a merger when the top management of both the firms agree that joining together will best serve their common interests and contribute to the increase of profitability and effectiveness of both the companies. However, when the deal is unfriendly, namely when the target company does not want to be purchased, the deal is always regarded as an acquisition.

With respect to the abovementioned distinction of mergers and acquisitions, it should be borne in mind that in practice there are few actual mergers of equals. What typically happens is that as part of the terms of the deal, when one company takes over another, the acquired entity is allowed to claim that the transaction is a merger of equals, even though it is an acquisition in all technical and legal respects. This policy is adopted mainly because the purchase of a firm often creates negative connotations for the acquired firm among investors and anyone else with an interest in the company. Therefore, the description of an acquisition as a merger of equals is part of the deal makers' and top managers' endeavor to make the takeover more palatable, to alleviate any resistance from the employees of the target company and to obviate any other opposition to the deal.

There are various types of mergers and acquisitions which are described in detail in this paper. Furthermore, the various incentives and motivations behind mergers and acquisitions are broken down. The counterincentives and the failures of mergers and acquisitions are also examined. In addition, the financing options in mergers and acquisitions are assessed. All of these issues are included in section 2 of this paper. Section 3 discusses the recent trends in mergers and acquisitions by providing a brief analysis of the major deals of the last two decades along with a relevant examination of the banking sector in the United States and Europe. The last issue examined in section 4 concerns the recent wave of acquisitions in the Greek banking sector. In this respect, all the recent transactions among the Greek banks are described but the focus is on the takeover of Emporiki Bank by Alpha Bank and the implications for the shareholders of Alpha Bank. The conclusions of the study are summarized in section 5 .

\section{Background elements}

\subsection{Types of mergers and acquisitions}

There are several types of mergers and acquisitions and several applicable dimensions or categorizations. As mentioned previously, one kind of distinction concerns the business sectors of the companies involved. More specifically, when the two 
companies operate in the same cluster, the transaction is considered to be horizontal, namely it concerns the efforts of a company (in the case of an acquisition) or two companies (in the case of a merger of equals) to boost their market share within their location or to expand their activities in new locations. When the acquiring entity and the target firm do not belong to the same sector, the merger or the acquisition is considered to be vertical and reflects the acquiring entity's strategy of entering new business sectors. A merger of this type is also called a "conglomerate merger". A vertical merger can be further broken down into 'forwards' or 'backwards' vertical mergers. The former allows commercial profits to be maintained within the company and the latter helps the company to undertake preliminary productive activities, for which it used to pay third parties.

In the case of horizontal mergers and acquisitions, the variety of the produced goods and services does not change significantly. In addition, there might be negative implications in a social and macroeconomic sense, such as the decline in healthy competition among the firms, which hinders the rationalization of prices charged and the improvement in the quality of the goods and services offered, as well as the development of monopolistic or oligopolistic markets, which usually has a detrimental effect on social welfare.

Another source of categorization concerns the "privatization" of the target firm. In particular, mergers and acquisitions are divided into "private" and "public" ones depending on whether the merging or acquired company is listed on a public stock exchange market or not. When the deal concerns a public company, its shares are usually, but not always, delisted as the acquisition of the majority or all of an entity's shares by one buyer is in opposition to the regulatory requirements for listed companies. These requirements stipulate the diversification of shares' owners and prohibit the ownership of listed firms being concentrated in the hands of one or a few shareholders.

An additional dimension or categorization refers to whether an acquisition is friendly or hostile. The identification of an acquisition as a friendly or a hostile depends on whether the target entity consents to the deal or not. In the case of the target entity not agreeing to the purchase bid, the transaction is regarded as a hostile takeover, via which the buyer "forcibly" takes absolute control of the acquiring company.

In the case of hostile takeovers, the target company may react via capital increase with priority given to the old shareholders (poison pill), counteroffers for the acquisitions of the bidder (packman defense), the repurchase of its own shares by the company itself, the creation of a negative climate for the company via asset and liability restructuring or via a merger with a third entity which is considered friendly by the Board of Directors (BOD) of the target firm. 
Whether an acquisition is considered friendly or not, significantly depends on how the proposed deal is communicated to and perceived by the target company's board of directors, employees and shareholders. In the case of a friendly transaction, the two companies negotiate the terms of the desired deal. On the contrary, in the case of a hostile takeover, the management of the target is unwilling to be acquired while the target's BOD has no prior knowledge of the offer. However, a hostile acquisition can ultimately become friendly, if the buyer ensures that the transaction is eventually sanctioned by the BOD of the acquired entity after improving in the offer's terms or relevant negotiations.

As mentioned above, an acquisition usually refers to a purchase of a smaller entity by a larger one. However, there are cases where a smaller company acquires management control of a larger firm or a firm that has been in business for longer than the acquiring company, and where the post-acquisition entity retains the name of the target company. This kind of transactions is called a reverse takeover. Similarly, there is the reverse merger, which takes place when a privately held company that has great potential and that is eager to raise funds on the stock market, purchases a publicly listed firm, usually one with no business and limited assets. This transaction enables the private company to become publicly listed in a relevantly short time in order to finance its developmental strategy and plans.

A further type of acquisition concerns the buyout of the target company's top management. In these cases, large companies of great economic magnitudes in terms of production, sales and profitability acquire the management of other smaller entities in order to exploit their particular knowledge and experience in the field in which the smaller firm operates. In other words, the big company seeks to take advantage of the "team capital" of the smaller firm, which can be more specialized, communicative, flexible and effective in comparison to the big company in several areas.

Another type of merger is the so-called "Joint Venture". This scheme concerns the cooperation of two or more different companies for the accomplishment of a common objective. Joint ventures often sail in uncharted waters and as such they are considered high-risk business plans with a high degree of uncertainty about their final outcome. This type of cooperation is common in the cases of large scale constructions of a public nature such as motorways, bridges and other infrastructure.

An additional form is the so-called "Leveraged Buy Out", which concerns the development and growth of a company via the assumption of debt in order to finance the acquisition of other entities, usually larger than itself. This is an aggressive developmental policy, which entails particularly high levels of risk for the firm relating to the high degree of leverage and the resulting extreme negative consequences should the plans financed by massive banking loans fail. 
A last point to make is that when referring to the concept of mergers and acquisitions, the terms "demerger", "spin-off" and "spin-out" are also applicable. These terms are sometimes used to indicate a situation where one company splits into two generating a second company separately listed on a stock exchange.

In addition to the above categorization of mergers and acquisitions, it should be pointed out that there are also a variety of structures used in securing control over the assets of a company, which have different tax and regulatory implications. In this respect, there is the case of the bidder purchasing the shares of the target firm and taking hold of the acquired company's control. Ownership of control in turn conveys effective control over the assets of the company. However, this form of transaction also carries with it all of the liabilities accrued by that business in the past and all of the risks that company faces in its commercial environment. Another example concerns the purchase of the target company's assets by the buyer. In such a case, the cash paid to the target firm by the vendee is paid back to the shareholders of the target as dividend or through liquidation. This type of transaction leaves the target company as an "empty shell", if the buyer buys out the entire assets. However, the buyer may choose not to buy all the assets and liabilities of the entity.

\subsection{Motivations behind mergers and acquisitions}

When assessing the factors which drive mergers and acquisitions among companies, a significant segment of the literature highlights the explanatory capital market forces. Nelson (1959) claims the expansion of mergers in the United States was closely related to the state of the capital market. The wave of acquisitions driven by stock market misvaluations have also been highlighted by other studies such as those of Shleifer and Vishny (2003) and Gang Bi and Gregory (2010).

Along with stock market forces, the literature on mergers and acquisitions offers a wide range of alternatives on why corporations engage in such corporate deals. The dominant rationale behind the activity of the companies involved in mergers and acquisitions is that acquiring firms can significantly contribute to the improvement of financial performance. The motives and benefits relating to the improvement of financial performance can be separated into three categories on the basis of the time needed in order for the expected benefits from the merger or the acquisition to accrue. The three categories considered include the short-run implications, the medium-run effects and the long-run impacts of the deal.

The immediate benefits expected from a merger or acquisition include various financial and economic factors. One of these factors relates to the earnings per share, the EPS ratio, of a listed company which effects the acquisition of another company. In 
particular, such business initiatives are expected to amplify the EPS ratio of the entity and create surplus value for its shareholders. In the same respect, another known financial ratio of the company that is expected to get improved by an acquisition is the price per earnings, the $\mathrm{P} / \mathrm{E}$ ratio, which is an indicator of the "premium" an investor is willing to pay for a unit of earnings made by the company. In terms of improving the $\mathrm{P} / \mathrm{E}$ ratio of the acquiring company, the main objective of an acquisition or a merger is to smooth the earnings results of the firm, which over the short-run or the longer-run smoothes the company's price on the board of the stock exchange, giving conservative investors more confidence to invest in the company.

Another short-term benefit relates to the various synergies than can be gained in several areas such as liquidity, production costs and sales. Ravenscraft and Scherer (1989) note that operating synergies can arise through the achievement of economies of scale and scope, the avoidance of performing duplicate activities, the pursuance of vertical integration, and the transfer of managerial skills and knowledge by the acquiring company to the target company. It should be also noted that, according to Comment and Jarrel (1995) and Andrade et al. (2001), operating synergies tend to arise mainly when the merging companies operate in the same or related sectors.

Typical examples of operating synergies include the case where a firm facing liquidity shortages and difficulties in financing its operation through the banking system seeks to merge with a healthier company which will have a better liquidity and credibility. This actually aims to improve cash flow stability and lower the risk of bankruptcy for companies facing financial hardships (Lewellen, 1971; and Higgins and Schall, 1975) as well as access to cheaper capital and an internal capital market (Bhide, 1990).

Another example of synergies concerns the interchange of managerial specialization and knowledge between the two companies. Within this context, some companies carry out acquisitions as an alternative to the normal process of hiring experienced employees and management executives. This is particularly common when the target is a small private company or is in the startup phase. In this case, the acquiring company simply hires the staff of the target private firm, thereby acquiring its talent and knowhow. The target private company simply dissolves and few legal issues are involved. The increased bulk-buying discounts that can be achieved by a large firm are also an example of short-term synergy benefits. Finally, synergies may include acquirement of technology as well as other tangible and intangible assets.

Despite the benefits expected from synergies, it should be notes that the achievement of synergies is a matter of fact and should be approached cautiously. As noted by Basmah and Rahatullah (2014) companies should approach vertical mergers cautiously as it is often difficult to gain synergy through such a merger transaction. 
Companies need to diversify their activity in order to improve their performance, increase the wealth of their shareholders and the value of their shares is another factor which motivates organizations to engage in mergers and acquisitions. In this respect, Servaes (1996) offers a comprehensive study of the value of diversification during the conglomerate merger wave.

Another frequently cited motivation concerns the usage of takeovers (and especially the hostile ones) as a force of discipline to correct managerial failures or nonalignment of incentives between managers and owners. Several studies, such as those of Hasbrouck (1985), Palepu (1986) and Mitchell and Lehn (1990) provide evidence that, prior to the acquisition, the performance of target firms in a hostile takeover is inferior to the performance of firms in a friendly takeover.

Cross-selling is an additional benefit that can accrue in a relatively short time frame after the merger or the acquisition. For example, a bank which decides to buy a stock brokerage firm obtains access to a wide range of new customers to whom it can sell its products. On the other hand, the broker can sell its products and services to the customers of the bank. Overall, a significant increase in the whole sales' volume and profitability is expected as a result of the deal between the two firms. This may be the case for a manufacturer who can acquire and sell complementary products. The benefits of cross-selling may be both short-term and longer-term.

Overcoming of entrance barriers to a market is another motivation behind a merger or an acquisition that can be beneficial in a relatively short time frame. Such barriers regard the investments needed for a company to enter a new market, such as the development of fixed assets, the launch of substitute products and their marketing, the power of the firms that are already established in the sector, as well as possible obstacles raised by government policy and regulatory requirements. In these cases, it is much easier for a company wishing to enter the market to do so via the acquisition of an entity that already operates in the market of interest.

Finally, there are considerable tax benefits expected from acquiring a company or merging with a company (Scholes and Wolfson, 1990). More specifically, a profitable company may buy a loss-making entity to use the target's accumulated taxable loss in its favor thus reducing its own tax liability. In this respect, it should be noted that in the United States and many other countries, rules are in place to limit the ability of profitable companies to acquire loss-making companies, limiting the possible tax motive of an acquisition. Other tax motivations may concern changes in the tax scale of the new scheme and the possible increase in the tax-free reserves built by the new entity. 
When it comes to the medium-term benefits from a merger or an acquisition, the most common relate to economies of scale and economies of scope that can be achieved by the new business arrangement. The former refers to the fact that the combined firm can often reduce its fixed costs by removing duplicate departments or operations, lowering the operating costs of the company relative to the same revenue stream, thus increasing profit margins. In addition, cost savings can also be attained as a result of the negotiating power of the new entity with its suppliers thus achieving better prices or higher discounts for the goods and services it receives. The latter relates to the efficiencies primarily associated with demand-side changes, such as increasing or decreasing the scope of marketing and distribution of different types of products.

Along with the boost in liquidity of the acquiring company at the short-run level, a general improvement in its financial position may be achieved in the medium-run. In this respect, the consolidated financial statements reporting increased assets, magnitudes and equity mitigate the risk run by the company's shareholders and creditors thus improving its ability to raise funds from the banking system with better terms and lower interest rates. The improvement of the company's financial position also relates to the decrease in the company's total indebtedness, which is possible given that an acquisition is expected to improve productivity, increase profitability and enhance cash flow.

Finally, on the question of long-run benefits from mergers and acquisitions for a company activating in this field, one of the main benefits concerns the strengthening of the firm's competitive position. More specifically, a big company usually outperforms its competitors. In addition, if the mergers and acquisitions activity results in the decrease in the number of participants in a particular market, the remaining players can reach an agreement that relaxes the competition among them, resulting in savings of resources consumed under conditions of intense competition while also maintaining their prices and profitability at a sufficiently high level.

Going further, synergies already achieved in the short- or the medium-term can be much more significant in the long-run. Additional synergies relate to the accumulated increase in the new entity's size and the identification of new business opportunities that can be exploited due to the size of the firm. These opportunities and the entire spectrum of possibilities in increasing productivity and profitability of the entity derived from the merger or acquisition cannot usually be fully assessed at the beginning of such an endeavor.

Another long-run result of a merger or an acquisition is that the creation of large multifarious corporations itself generates new chances for further development via new mergers and acquisitions. In this way, the companies are better equipped to face 
the challenges of globalization and international competition while they also become more capable of tackling unwanted offers and hostile takeovers.

Moreover, the reduction in the costs and time needed for the development of a new product is another motivation behind an acquisition, which has long-run implications. In particular, an innovation or the diversification of production is known to be time consuming, namely much time must pass before the innovation becomes productive and generate profit for the company. In addition, innovations usually carry a high risk of failure. Therefore, in many cases the management of a company decides to pay a high price to acquire an entity that already operates in the sector of interest rather than bearing the costs and risks of developing of a new product from scratch.

We conclude this section on the motivations behind mergers and acquisitions by noting that these deals usually create surplus value for the shareholders of the dominant company. They may also create value for the shareholders of the acquired or merging entity under certain conditions. However, the consequences for the economy and society as a whole are multifold and sometimes controversial.

\subsection{Counterincentives and failures of mergers and acquisitions}

Along with the wide range of motivations and benefits relating to mergers and acquisitions, there are also several counterincentives contributing to the failure of such transactions that need to be broken down. One key source of failure concerns the personal interests of the target company's executives and employees. These interests regard the compensations, bonuses and other benefits offered to them by the target company and their fear that the new ownership might reduce or revoke them. In addition, there are fears among the acquired entity's personnel that there might be abolition of several positions driving them to the unemployment. Practically, this is the case for the majority of mergers and acquisitions. However, the number of people losing their occupation varies depending on the proliferation of the departments and services as well as the size of staff between the acquiring and redeemed firms.

Another significant issue, which quite often causes negative effects on the chances a merger or an acquisition stands of being successful, concerns the cultural differences between the companies involved. The collision between the business cultures of the entities halters the realization of all or some of the expected benefits from the deal. The competition between the managing boards of the two companies is also another example of cultural conflicts along with the pecuniary implications of management conflict. The cultural differences may also result in delays in the prompt consolidation of the entities, delays that might lead to the withdrawal of the plans about the merger or acquisition. 
In addition to the above factors, the frequency and quality of communication of the expected benefits to the target company's staff also is crucial for the accomplishment of the goals set via a merger or an acquisition. It has been observed that quite often the communication between the management of the acquiring company and the people of the acquired entity is poor. This lack in communication along with the dismissals of personnel that frequently take place results in the deal not meeting the expectations. With respect to dismissals, the probability of failure is even greater if the withdrawals are not voluntary.

Another source of failure concerns the lack of a suitable strategic plan framed under rational expectations after carefully assessing all the available resources as well as the possible outcomes. In this respect, the planning of a strategic merger or acquisition based on non-rational and over-optimist expectations about the synergies, economies of scale and the profits to be made via such a deal provides the market with a wrong view of the possibilities of the scheme that is to be created and ultimately leads to the failure of the entire venture. Additionally to the lack of a comprehensive strategic plan, the hastiness occasionally observed in completing a deal without performing a thorough and qualitative financial, economic and legal audit of the target firm also contributes to the failure of the endeavor. The lack of a full recognition of the changes that will occur in the structures of the target firm is another element being within the concept of the above factors that also exerts a negative impact on the chances of success of a merger or an acquisition.

Going further, the price paid for an acquiring entity might be too high to help the deal succeed. This issue relates to the techniques used for the evaluation of the target company. With respect to the evaluation techniques, there are several possibilities. One of these possibilities regards the method of Net Present Value, according to which the value of the target firm reflects its current value in the market. Other possibilities in evaluating the company that is to be acquired relate to the Book Value and the Current Value of the company in the stock exchange market.

Finally, the general market and economic conditions along with the legal and institutional framework are of high importance for the success of an acquisition or a merger. In this respect, unfavorable laws or governmental interventions along with possible negative or even hostile macroeconomic and entrepreneurial environment may lead to the total cancelation of a merger or acquisition or the failing of achieving its aims and goals.

\subsection{Financing mergers and acquisitions}

One element to distinguish between mergers and acquisitions relates to their financing in addition to the size of the companies involved. In regards to the latter, as previously mentioned, the entities involved in a merger are usually of about the 
same size while in an acquisition there are significant differences in the magnitude of the acquiring company and the target firm.

With respect to the financing of such deals, there are possible ways to go forward. One obvious possibility is the payment in cash. Cash transactions usually reflect acquisitions rather than mergers because the shareholders of the acquired entity redeem their shares and are removed whereas the entity comes under the absolute control and management of the acquiring company. With respect to the cash option, a range of studies has shown that mergers and acquisitions are frequently financed via the issuance of debt. (see, e.g., Bharadwaj and Shivdasani, 2003; Faccio and Masulis, 2005, Harford et al. (2009); and Uysal, 2011). Moreover, Karampatsas et al. (2013) find that bidders holding a credit rating and/or having a higher rating level are more likely to use cash financing in a takeover.

An alternative way to finance such a transaction is via the issuance of stocks on behalf of the acquiring company and the transfer of them to the shareholders of the target firm. These stocks are issued at an agreed ratio proportional to the value of the target company. In these cases, the shareholders of the acquired company are not removed and still hold a proportional control in the new entity. According to Shleifer and Vishny (2003), firms make stock-financed acquisitions when their own equity is highly valued, and in particular when their equity is more highly valued than that of the target company.

In cases of mergers, it is standard practice for the two parties to cancel the shares of the old companies and issue new shares for the consolidated entity. In these cases, an evaluation of both companies is performed before the issuance of the new shares. The evaluation helps the determination of the new entity's value and also helps the sharing of new stocks between the two parties.

Overall, there are some general elements that must be taken into account when choosing the form of payment for a merger or an acquisition. One element concerns the possible existence of other offers for the target firm. Both the size of the offers and their payment method may be crucial in order for the target company to decide on which bid to go for. In this respect, it is highly possible that clear cash offers supersede other types of offers and tackle the completion of the other bids.

Taxation is another significant factor that affects financing and the overall decision on a merger or acquisition deal. For this reason, competent accounting and tax advisors are usually employed to perform relevant due-diligences and establish the most advantageous proposal.

Going further, the possible effects on the buyer's capital structure from an acquisition must not be neglected. In particular, if the financing of the acquisition is to be per- 
formed via the issuance of new shares on behalf of the acquiring company with a relevant capital increase from its shareholders and the transfer of the shares to the target firm's stakeholders, the shareholders of the buyer might halter this capital increase at their general assembly. Such a risk does not exist if the acquisition is to be executed by a cash payment.

Moreover, the possible effects on the balance sheet and the financial ratios of the buyer are also important when deciding on the form of payment for an acquisition. More specifically, when the transaction is to be funded by cash, the liquidity ratios of the buyer might be harmed. The harm will be even greater if the buyer does not have enough cash on its own and needs to sign a relevant loan with a financial institution. On the other hand, in a pure stock-for-stock transaction, the acquiring entity might report worsened profitability ratios if the profits remain stable while the volumes of assets or capital increase.

Another element to be considered is that there is a close link between the payment method and the financing options. More specifically, if the acquiring firm will pay for the transaction in cash, it has two main financing options. The first option is the usage of cash on hand. In these cases, the acquiring company has sluggish cash that can be used for the financing of its expanding plans. In case it uses its own cash on hand, there are no major transaction costs to be borne. The second option relates to the existence of unused debt capacity. If the company uses this capacity to fund the deal, it will worsen its debt ratio and increase its borrowing costs. The transactions costs involved are also greater than those in cash on hand payments.

If the buyer pays for the acquired entity via a stock-for-stock scheme, there are two financing possibilities. The first is the issuance of new shares, which may improve the indebtedness ratio of the company and reduce cost of debt. This kind of transactions includes the fees paid for the preparation of a relevant file for the capital increase (auditors, publications, etc.) along with the costs incurred for holding an extraordinary assembly of shareholders. The second financing option concerns the shares in treasury. This means that the acquiring company needs to use the existing shares for the implementation of the stock-for-stock payment scheme. If the company happens to hold some of its own shares, it can use them. In any other case, the company needs to repurchase the necessary shares from the market. These actions may incur positive effects on the debt ratio and the borrowing costs of the company. On the other hand, if the company proceeds with the repurchase of stocks from the market, there are brokerage fees that must be paid.

A last element that needs to be considered in the financing of mergers and acquisitions is that, in general, the payment method is a way to indicate value. Paying 
cash or with shares is a way to signal value to the other party. More specifically, if the buyer is willing to offer stock for the payment, the directors of the target company should suspect that the buyer believes that its stocks are overvalued with respect to their actual value. On the contrary, if the bidder tends to pay by cash, it will be a signal that it believes that its stocks are undervalued.

\section{Historical evolution and recent trends in mergers and adquisitions}

\subsection{Merger and acquisitions waves}

The history of mergers and acquisitions as a means for the development and expansion of companies well exceeds the one hundred years. Economic history has identified at least six significant waves of mergers in the business world. ${ }^{1}$ The first one (The Great Merger Wave) lasted about ten years from 1895 to 1905 . This is characterized by horizontal mergers via which small entities having weak market share merged with similar firms in order to create large and powerful schemes so as to boost their position in the market they operated. The vehicle that was used was the so-called "trusts". Companies such as DuPont, US Steel and General Electric underwent mergers and acquisitions during the Great Merger Movement and became able to maintain their dominance in their respective sectors till today, due to the technological advances of their products, patents and brand recognition by their customers.

The second wave spans the period 1916-1929. This wave is characterized by vertical mergers, namely the mergers of companies operating in different business sectors with a view to achieving vertical integration and development.

The third wave is located between 1965 and 1969. During this wave, the corporate marriages involved more diverse companies and resulted in the rise of significant conglomerate schemes. The buyers frequently entered different business sectors and industries in order to hedge their production against cyclical bumps or to diversify their investments portfolio.

The fourth wave of massive mergers and acquisitions took place over the period 19811989. The dominant characteristic of this wave is that the majority of the deals concerned hostile takeovers and aggressive corporate raiding. Many companies were

\footnotetext{
' Refer to the following link for more details on the history of the six waves of mergers and acquisitions:

http://osgoode.yorku.ca/media2.nsfl589 I 200 I c09 Icdc8852569300055bbf9// e377/ 92325 I 7fd085257 l ef0070 I 385/\$file/me rger\%20waves_toronto_lipton.pdf.
} 
acquired for their soft capital such as the patents they had developed, the licenses they had registered, their market share and brand name, their research staffs and facilities, as well as their customer base and culture.

The fifth wave was observed during the period 1992-2000. The main feature of that period was that the majority of deals concerned cross-border transactions. During that period, the buyers sought out entities operating in a similar or homogenous sector in another country in order to globalize their activity and enhance their capacity to serve their customers at an international or global level. The goal was to expand their global footprint and become more agile at creating high-performing businesses and cultures across national boundaries.

Finally, the sixth and so far the last wave of mergers and acquisitions lasted about six years during the period 2003-2008. The main characteristics of this wave is that the transactions that took place were the result of shareholder activism and mainly involved leveraged buyouts (acquisitions financed by loans) and the increase in activation of private equity. 2008 is the year that the economic recession burst out in the United States and started spreading to other continents. Among other effects, the economic crisis resulted in a major decrease in significant corporate deals worldwide.

With respect to the most significant corporate deals that took place over the last two decades, Table 1 reports relevant data on the Top 10 of deals. The data presented includes the ranking number of each transaction, the year the transaction took place, the names of the buyer and the acquired company, and the transaction value in \$mil. The table is split into two panels. Panel A reports data for the decade from 1990 to 1999 and Panel B provides corresponding data for the period from 2000 to 2010.

\section{Table 1. Top 10 mergers and acquisitions deals worldwide by value}

\section{Panel A: Decade 1990-1999}

\begin{tabular}{llllc}
\hline Rank & Year & Purchaser & Purchased & Transaction value (In Smil.) \\
\hline 1 & 1999 & Vodafone Airtouch PLC & Mannesmann AG & 183,000 \\
\hline 2 & 1999 & Pfizer & Warner-Lambert & 90,000 \\
\hline 4 & 1998 & Exxon & Mobil & 77,200 \\
\hline 5 & 1998 & Citicorp & Travelers Group & 73,000 \\
\hline 6 & 1999 & SBC Communications & Ameritech Corporation & 63,000 \\
\hline 7 & 1999 & Vodafone Group & AirTouch Communications & 60,000 \\
\hline 8 & 1998 & Bell Atlantic & GTE & 53,360 \\
\hline 9 & 1998 & BP & Amoco & 53,000 \\
\hline 10 & 1999 & Qwest Communications & US WEST & 48,000 \\
\hline
\end{tabular}


Panel B: Decade 2000-2010

\begin{tabular}{|c|c|c|c|c|}
\hline Rank & Year & Purchaser & Purchased & action value (In \$mil.) \\
\hline 1 & 2000 & America Online & Time Warner & 164,747 \\
\hline 2 & 2000 & Glaxo Wellcome Plc. & SmithKline Beecham Plc. & 75,961 \\
\hline 3 & 2004 & Royal Dutch Petroleum Company & Shell Transport \& Trading Co. & 74,559 \\
\hline 4 & 2006 & AT\&T Inc. & BellSouth Corporation & 72,671 \\
\hline 5 & 2001 & Comcast Corporation & AT\&T Broadband & 72,041 \\
\hline 6 & 2009 & Pfizer Inc. & Wyeth & 68,000 \\
\hline 7 & 2000 & Spin-off: Nortel Networks Corporation & & 59,974 \\
\hline 8 & 2002 & Pfizer Inc. & Pharmacia Corporation & 59,515 \\
\hline 9 & 2004 & JPMorgan Chase \& Co. & Bank One Corporation & 58,761 \\
\hline 10 & 2008 & InBev Inc. & Anheuser-Busch Companies, Inc. & 52,000 \\
\hline
\end{tabular}

SOURCE:WWW.WIKIPEDIA.COM

According to the data in Table 1, the most significant deal in terms of cost in the decade 1990-1999 was the acquisition of 35\% shares in Mannesmann AG by Vodafone Airtouch PLC in 2000 in a tax-free stock exchange of 53.7 Vodafone shares for each share of Mannesmann. This deal raised a lot controversy as never before in Germany had a large company been acquired by a foreign owner. This was a hostile takeover which was backed in a private deal between Mannesmann management and Vodafone. ${ }^{2}$ The cost of this deal reached $\$ 183$ billion. The name Mannesmann ceased to exist in the telecommunication sector soon after the deal with Vodafone had taken place.

On the other hand, the "cheapest" deal of the decade was that between Worldcom and $\mathrm{MCl}$ Communications. On November 4, 1997, WorldCom and MCl Communications announced their $\$ 37$ billion merger to form $\mathrm{MCl}$ WorldCom, making it the largest merger in US history. The new company, MCI WorldCom, opened for business on September $15,1998 .^{3}$

In the first decade of the $21^{\text {st }}$ century, the most significant deal was that between American Online (AOL) and Time Warner, which amounted to about $\$ 165$ billion.

\footnotetext{
${ }^{2}$ Refer to http://en.wikipedia.org/wiki/Mannesmann.

${ }^{3}$ It should be noted that beginning in mid-year 1999 and continuing through May 2002, the company used fraudulent accounting methods to mask its declining earnings by painting a false picture of financial growth and profitability to prop up the price of its stock. The fraud was primarily accomplished in two ways. The first relates to the booking of 'line costs' (interconnection expenses with other telecommunication companies) as capital on the balance sheet instead of expenses. The second way concerns inflating revenues with bogus accounting entries from "corporate unallocated revenue accounts". The fraud was revealed and communicated to the company's audit committee and board of directors by a team of the company's internal audit department. The people involved were fired, the external auditor (Arthur Andersen) withdrew its audit opinion for 200 I, and the U.S. Securities and Exchange Commission launched an investigation on June 26, 2002. By the end of 2003, it was estimated that the company's total assets had been inflated by around $\$ 1$ I billion. On July 2I, 2002, WorldCom filed for Chapter II bankruptcy protection in the largest such filing in United States history at the time. The company emerged from Chapter II bankruptcy in 2004 with about $\$ 5.7$ billion in debt and $\$ 6$ billion in cash. About half of the cash was earmarked to pay various claims and settlements. Previous bondholders ended up being paid 35.7 cents on the dollar, in bonds and stock in the new MCl Company. The previous stockholders'stock was cancelled, making it totally worthless (refer to http://en.wikipedia.org/wiki/MCI_Inc.\#MCI_acquisition).
} 
The deal was announced on January 10, 2000 and officially filed on February 11, 2000. It employed a merger structure in which each original company merged into a newly created entity. The Federal Trade Commission cleared the deal on December 14, 2000 and gave final approval on January 11, 2001 while the completion of the deal took place later that day. Due to the larger market capitalization of AOL, they would own $55 \%$ of the new company while Time Warner shareholders owned only $45 \%$, so in actual practice AOL had acquired Time Warner, even though AOL had far fewer assets and lower revenues. ${ }^{4}$

Finally, the least expensive transaction in the first decade of the new century was the purchase of Anheuser-Busch Companies, Inc, an American brewing company, by InBev Inc, a Belgian-Brazilian brewing company. On June 12, 2008, InBev announced that it had made a US\$ 46 billion dollar offer for the company. InBev also stated that they would attempt to retain management and board members from both companies. On June 25, 2008, Anheuser-Busch announced that they would reject the offer. On July 1, 2008, InBev urged Anheuser-Busch's shareholders to vote in favor of the buyout as InBev felt the offer of $\$ 65$ per share should be considered a reasonable offer in view of the falling stock market. On July 7, 2008, Anheuser-Busch filed a lawsuit against InBev to stop them from soliciting the support of shareholders, stating that the company's offer was illegal. On July 13, 2008, Anheuser-Busch and InBev finally said they had agreed to a deal, pending shareholder and regulatory approval, for InBev to purchase the American icon at $\$ 70$ per share, creating a new company to be named Anheuser-Busch InBev. Anheuser-Busch would get two seats on the combined board of directors. The all-cash agreement, almost $\$ 52$ billion in total equity, created the world's largest brewer producing significant brand names such as Budweiser, Michelob, Beck's and Stella Artois. ${ }^{5}$

\subsection{International trends in merger and acquisitions waves}

It has been historically observed that the waves in the United States are correlated to high growth rates in the economy after the end of wars or as a result of major technological innovations. The favoritism to mergers and acquisitions displayed by the American governments throughout the business history of this country also contributed to the relevant waves of this kind of corporate activity. In addition, the conflict of interests between the managing boards and the shareholders of companies has also contributed to the evolution of mergers and acquisitions as one major vehicle for the expansion of the entities.

${ }^{4}$ Refer to http://en.wikipedia.org/wiki/Time_Warner for the details reported on this transaction between AOL and Time Warner.
${ }^{5}$ The information provided on this deal is found on http://en.wikipedia.org/wiki/Anheuser-Busch. 
On the other side of the ocean, in Europe, the major factor that induced the activity of European entities was the creation of the Unified European Market. The deregulation and the intensity of global competition also contributed to the increase in mergers and acquisitions in the European continent. The reform of credit and banking systems in Europe also created opportunities for profitable consolidations. Furthermore, the collapse of the socialist regimes in Eastern Europe and the consequent denationalization of neuralgic state companies gave rise to new business possibilities and new markets. In this respect, many companies mainly from the banking sector proceeded to the acquisition of local companies in order to immediately penetrate the local markets. Moreover, the transformation in the type of the average European company also contributed to the increase in mergers and acquisitions activity. The transformation refers to the reduction in the significance of family-owned companies and the emergence of major publicly owned companies.

Up to 2008 the trend in the field of mergers and acquisitions was positive and a spectacular growth in the relevant transactions could be observed, especially in the case of megamergers, that is the merger of two giants in their sector such as the hostile takeover of Mannesmann AG by Vodafone Airtouch PLC in 1999. It should be noted that while the megamergers started out as an American phenomenon, it became more national in the process. The above mentioned deal reached was between a German and a British company testifies to this fact.

As far as the comparison between the United States and Europe is concerned, Figure 1 indicates that the total value in mergers and acquisitions in the United States is by far greater than that in Europe. Furthermore, this figure shows that mergers and acquisitions flourished after 1994 and reached their peak in 2000 for the U.S. and 1999 for Europe. Afterwards, a significant slowdown took place between 2000 and 2004 in both continents while a recovery happened during the period 2004-2007.

Over the years, mergers and acquisitions have been an efficient vehicle for the development of companies in the US and to a lesser degree in Europe whereas Australia has only participated in the fifth wave of 1992-2000 and the sixth wave of 2003-2008. However, this is not the case in Asian countries. Figure 2 shows that the Asian countries have not been very active in this field. The companies of Japan, which was the second biggest economy in the world before losing its place by China in 2010, got involved in such corporate actions only recently during the sixth wave as a result of the increase in the volume of commercial transactions with other countries. The restructuring of the Japanese economy that started in 1999 also contributed to the increase in mergers and acquisitions in this country. 
Figure 1. Mergers and acquisitions in U.S and Europe over the period 1980-2007
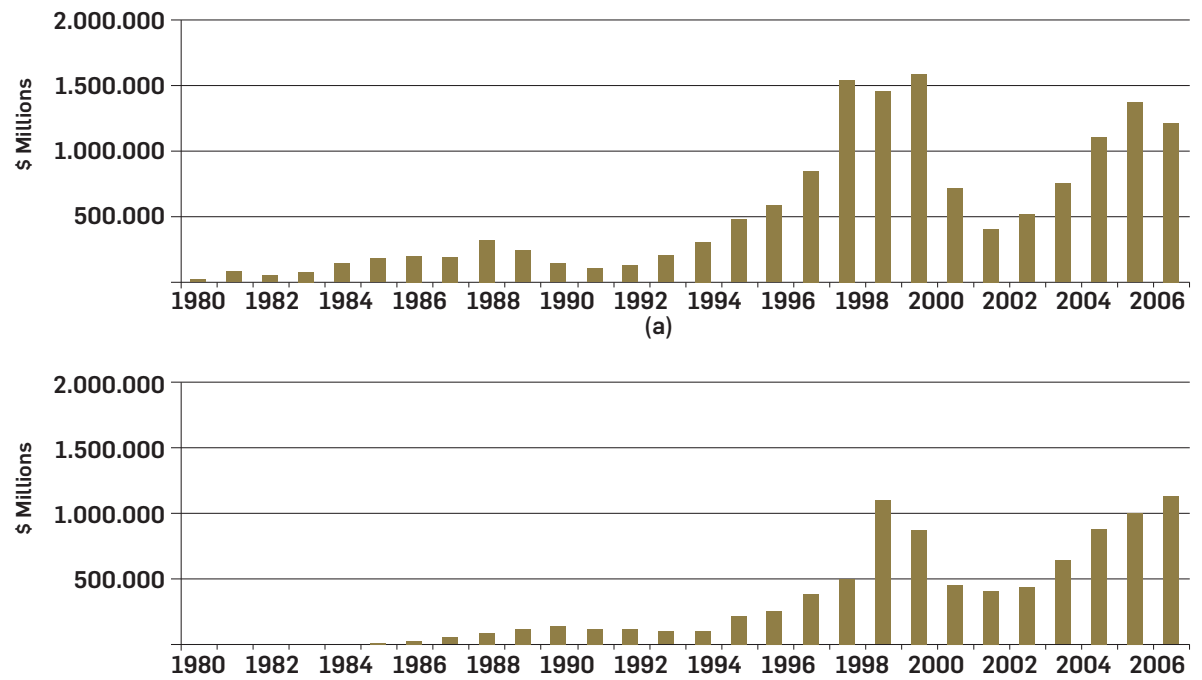

(b)

SOURCE:THOMSON FINANCIAL

Part (a) of figure concerns the United States and Part (b) concerns Europe.

\section{Figure 2. Mergers and acquisitions in Australia and Asian countries} over the period $1980-2007$
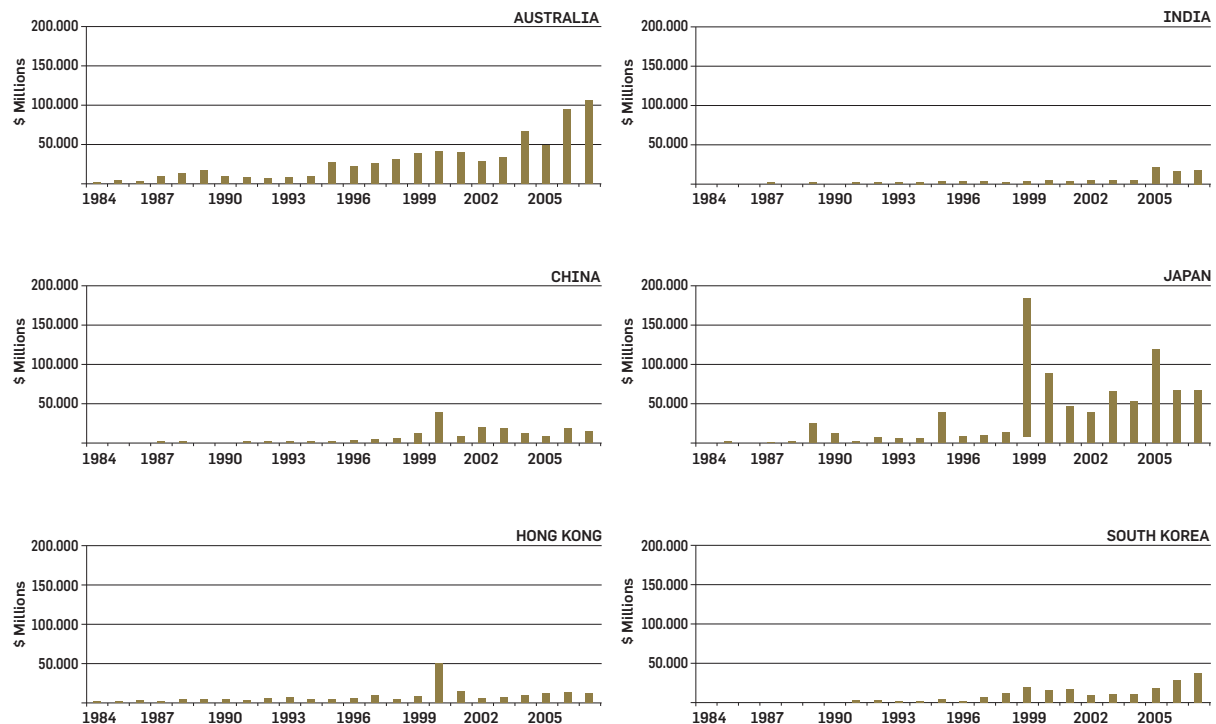

SOURCE:THOMSON FINANCIAL

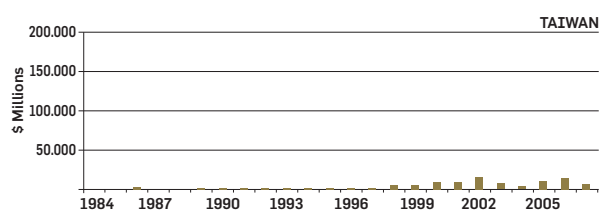


Furthermore, in terms of mergers and acquisitions in the other major Asian economies, Figure 2 shows that this kind of corporate activity in China, India, Hong Kong, Taiwan and South Korea is rather poor. The reasons for this drawback mainly relate to economic and political rigidities in these countries. However, Figure 2 shows that something seems to change at the end of the examined period. That is, we start to see some hesitant steps forward in mergers and acquisitions mainly as a result of the restructuring of their economies that is in process.

\subsection{Mergers and acquisitions in the banking sector}

Banks have three courses of actions to choose from in order to respond to the changes that take place in the banking sector as a result of the changes in the institutional framework and macroeconomic environment worldwide. The first course concerns the enhancement of their national basis via the cooperation with other local financial institutions in order to protect themselves against international competition. The second choice is cooperation with banks from other countries with mutual participation in the capital of the cooperating organizations. This policy is aimed at forming powerful international institutions capable of competing other big players of the banking sector. The third option is investment in other banks located in other countries through mergers and acquisitions.

Mergers between banks are expected to generate significant economies of scale in the supply of financial services and the vending of such products. The restructuring of their sales networks along with the reorganization of central services can result in significant cost savings and the optimization of banks' operating effectiveness. In this respect, the integration of information technology systems can contribute to a significant decrease in fixed costs after the transition period needed for the establishment of a well-functioning unified information system. In addition, the surplus productive capacity may be efficiently utilized.

Banking firms in the United States have been quite active in the field of mergers and acquisitions since the 1980s. Mergers and acquisitions can be particularly important in order for the small- to medium- size banks to increase their power in the local state market and enhance their chances of becoming strong national banking institutions. The choice of their names such as for example those of Nations Bank and Bank of America are indicative of their intentions and aspirations.

Contrary to the activity in the US, the banking sector in Europe has been less active in the field of mergers and acquisitions. However, this stance has started to be changing. Countries such as the Netherlands or Italy seem to be more aggressive than other member states in this regard. In addition, the main feature of the transactions 
in Europe is that the deals are basically between banks from the same country. This phenomenon is mainly due to the knowledge of the local markets common to two banks sharing the same roots and the increased probability they stand to achieve considerable economies of scale, synergies and optimization of their operations. Their common origin alleviates the negative effects of asymmetric information and uncertainty.

Contrary to the abovementioned more-or-less theoretical analysis of the expected benefits from mergers and acquisitions in the banking sector, a study conducted by the Federal Reserve Bank of Minneapolis has highlighted that the actual benefits in terms of economies of scale and improvements in operating effectiveness were inferior to the expected ones in the case of American banks. This failure to gain the expected benefits is attributed to the fact that the majority of deals took place between sizeable banks, whose potential for increasing their operating effectiveness due to economies of scale is lower than that of small banks. On the other hand, the volume of mergers between small banks is not so significant that it would affect the conclusion about the overall impact of mergers and acquisitions in the banking sector in US In another study, Borio and Tsatsaronis (2005) also showed that the actual results from mergers and acquisitions have fallen short of meeting expectations. Finally, Berger and Humphrey (1991) demonstrated that the mergers of banks in the United States did not result in the desired cost savings.

The quotation of the results of the empirical results above indicate that mergers between financial institutions is not a corporate action that immediately and definitely provides value for their shareholders, customers and economy in general. Consequently, such ventures need to be carefully designed and planned taking all the factors into account along with the possible frictions and other uncertainties that may be crucial to the final outcome.

\section{Mergers and acquisitions in the Greek banking sector}

\subsection{The recent wave of acquisitions in the Greek banking sector}

Over the last months, the so-called Greek "systemic" banks displayed intense activity in the field of mergers and acquisitions which resulted in a radical transformation of the whole Greek banking sector. More specifically, Piraeus Bank was the most active, acquiring the ATE Bank, Millennium Bank, Geniki Bank and three Cypriot banks operating in Greece doubling this way its loans portfolio. Eurobank obtained the Hellenic PostBank and the Proton Bank increasing its portfolio of loans by $15 \%$. Alpha Bank increased its loans portfolio by $27 \%$ through acquiring the Emporiki Bank from 
Credit Agricole. Finally, Ethniki Bank, the biggest Greek bank, was the least active and only purchased Probank, adding 5\% of new loans to its portfolio. ${ }^{6}$

The recent movements in the Greek banking sector accentuated Piraeus Bank as the winner in terms of increased loans and deposits and Ethniki Bank as the bank with the most robust and less precarious portfolio having the less doubtful receivables and the highest loans to deposits ratio compared to the other systemic banks. In addition, Alpha Bank is the bank with the best liquidity structure among the four systemic banks being simultaneously the least dependent Greek bank on the Central European Banking System. Finally, Eurobank managed to improve its basic figures considering liquidity, doubtful debts and loans to deposits ratio. At the consolidated level, the four Greek major banks control the $91 \%$ of total Greek loans market. This percentage is considerably higher than the respective figures for Portugal (60\%), Turkey (53\%), Italy (51\%), Germany (42\%), Spain (41\%) and Poland (41\%).

In order to provide an explanation for the recent intense activity in the Greek banking sector, we should note that while the typical incentives behind such transactions are similar to those broken down in section 2.2, in the case of the transactions described above the main driving factor was different. In particular, the "haircut" of Greek bonds in March 2012 mandated by the PSI program, which was selected as a decisive solution to the Greek sovereign debt problem, resulted in huge losses for the private holders of Greek bonds. This was the case for the Greek systemic banks too, which were obliged to realize significant losses in their balance sheets after the haircut of the Greek sovereign bonds included in their portfolios. The consequent need for the re-capitalization of banks aiming at the stability and robustness of the Greek banking and finance system triggered the recent wave of acquisitions among the Greek banks.

\subsection{Case study: the acquisition of Emporiki Bank by Alpha Bank}

\subsubsection{The details of the deal}

The Alpha Bank Group provides a wide range of services in Greece, Cyprus and Eastern Europe mainly covering the traditional banking operations, leasing, factoring, corporate and investment banking, asset management, real estate and hotel services. In developing its business the parent company Alpha Bank has pursued both internal growth strategies by establishing new bank affiliates in several foreign countries (e.g. Alpha Bank Romania S.A.) and development strategies by acquiring other bank organizations such as the loniki Bank, which was acquired in March 1999 and fully absorbed by Alpha Bank in April 2000.

\footnotetext{
${ }^{6}$ Information on the activity of the Greek banking sector and loans and other market shares was found in a report by Kathimerini on
} 5/9/2013. 
The most recent endeavor of Alpha Bank in the field of mergers and acquisitions relates to the purchase of Emporiki Bank, which was announced on 16 October 2012. The legal merger of Emporiki Bank with Alpha Bank was completed on 28 June 2013 via the absorption of Emporiki Bank by Alpha Bank. The new organization has a broad network of over 1,200 service points in Greece and a robust capital structure exceeding the $€ 6.7$ billion (according to the interim financial statements as at 30 September 2013 found on the website of Alpha Bank).

According to the press announcement made by Alpha Bank on 1 February 2013 in regards to the completion of the transfer of Emporiki's shares to Alpha Bank, the transaction contributed 2.7 billion Euros of net assets (equity) to Alpha Bank as well as a loans portfolio of high value covered by $22 \%$ with relevant provisions of 4.9 billion Euros. Moreover, the new organization will have a $20 \%$ market in deposits and a $24 \%$ market share when it comes to loans mainly focusing on housing and corporate credit and mainly on the industrial and constructive sectors. Going further, substantial annual synergies of 200 million Euros are expected to accrue for a period of three years after the completion of the merger between the two banks.

As far as the expected synergies of 200 million Euros are concerned, 150 million Euros regard synergies from cost restructuring with respect to the network, the avoidance of duplicate operations and the economizing on third parties' fees and remunerations. The rest 50 million Euros will derive from adjustments to the pricing policies of Emporiki Bank in the field of time deposits, the boost in sales of higher profit margins due to the increased market and customers' confidence in the new organization, and the realization of cross-selling activities.

\subsubsection{The implications for Alpha Bank's share price}

\subsubsection{Literature and methodological issues}

In addition to the business features of Emporiki Bank's acquisition by Alpha Bank described above, some empirical work is performed on the implications of this deal for the share price of Alpha Bank. In this respect, the literature has shown that a variety of factors can affect the share value of the bidding and the target companies at the announcement of corporate takeovers.

First, the studies of Goergen and Renneboog (2004), Gregory (1997), Franks and Mayer (1996) and Servaes (1991) have shown that the announcement of hostile takeovers results in higher and lower returns for the target and the bidding companies respectively than the announcement of friendly takeovers.

Another pattern revealed relates to whether the management of the bidding company owns large portions of the bidding company's shares and the impact of this fact on 
the share price of the company. According to the studies of Healy et al. (1997) and Agrawal and Mandelker (1987), when managers do not own equity, the agency costs in the company increase. This increase in agency costs is discounted in the share prices of the bidding companies because the shareholders will probably believe that the managers of their company they do not work in the interest of the owners but rather implement self-rewarding growth strategies.

Moreover, the literature has shown that the announcement of cash transactions entails higher returns for the bidder and the target than is the case with equity transactions. Several studies such as those of Franks et al. (1991), Andrade et al. (2001), and Moeller et al. (2004) have demonstrated that the announcement of an equity bid may create the impression that the bidding managers believe that their firm's shares are overpriced, such that investors adjust the bidders' share prices downwards.

Another element highlighted in the literature is that the acquisition of valuecompanies results in returns both for the bidding and the target company. Rau and Vermaelen (1998) demonstrate that the acquisition of companies with low marketto-book ratios generates high abnormal returns for the bidding firm's shareholders. On the contrary, the takeover of firms with high market-to-book ratios results in significant negative abnormal returns for the shareholders of the acquiring company.

A final element concerns the different return implications for the companies involved according to whether the transactions are domestic or cross-border. In this respect, several studies such as those of Wansley et al. (1983), Dewenter (1995) and Danbolt (2004) have shown that the target companies in cross-border deals tend to gain larger abnormal returns than their counterparts in domestic bids. A further consequence revealed by Conn et al. (2005) is that the share price of companies acquiring foreign firms significantly underperforms that of bidders participating in domestic takeovers.

The price reaction of Alpha Bank's share to the announcement of Emporiki Bank's takeover is investigated following the approach found in Martynova and Renneboog (2006). More specifically, the price reaction to the announcement made on 16 October 2012 is calculated by computing the abnormal returns of Alpha Bank's share around the announcement date. Abnormal return is defined as the difference between the realized return and the expected return of the share. This definition of abnormal return is shown in the following equation:

$$
A R_{t}=R R_{t}-E\left(R_{t}\right)
$$

where $A R_{t}$ denotes the abnormal return on day $t, R R_{t}$ is the realized return on the same day and $E\left(R_{t}\right)$ is the expected return on the same day. The expected return [or 
benchmark return in Martynova and Renneboog (2006) terms] is calculated using equation (2).

$$
E\left(R_{t}\right)=\hat{\alpha}+\hat{\beta} R_{m, t}
$$

where $R_{m, t}$ is the actual market return on day $t$. In order to obtain the alpha and beta coefficients used in equation (2) for the computation of expected return of Alpha Bank share, we apply two alternative models. The first one is the market model expressed in equation following (3):

$$
R_{A B, t}-R_{f}=\alpha_{A B}+\beta_{A B}\left(R_{m, t}-R_{f}\right)+\varepsilon_{A B, t}
$$

where $R_{A B, t}$ is the actual return of Alpha Bank share on day $t, R_{m, t}$ is defined as in above, $R_{f}$ is the risk-free rate expressed by the 12 -month Euribor, and $\varepsilon_{A B}$ is the residual of the regression (i.e. return portion which is not explained by the model).

The second model used for the calculation of alpha and beta coefficients to be used for the calculation of Alpha Bank's expected return is the model of Dimson (1979). This model is depicted in equation (4).

$$
R_{A B, t}=\alpha_{A B}+\beta_{A B}^{(-1)}\left(R_{m, t}-R_{f}\right)^{(-1)}+\beta_{A B}^{(0)}\left(R_{m, t}-R_{f}\right)^{(0)}+\beta_{A B}^{(+1)}\left(R_{m, t}-R_{f}\right)^{(+1)}+\varepsilon_{A B, t}
$$

where $(-1)$ indicates 1 time lag and $(+1)$ one time lead.

The usage of the model of Dimson (1979) aims at controlling for non-synchronous trading which may cause a downward bias on the estimation of beta. Based on Dimson model, the beta coefficient that will be used in equation (2) is the sum of the three beta coefficients of model (4).

Following Martynova and Renneboog (2006), the parameters of the above models (3) and (4) are estimated over a period of 240 trading days starting from 300 days before the announcement of 16 October 2012 and ending 60 days before the announcement. The parameters during the event window spanning 60 days before and 60 days after the announcement (120 trading days in total) are then estimated. In addition, to Martynova and Renneboog (2006), The models are run separately for each one of the two sub-intervals of the event window (60 days before and 60 days after the announcement). This is in order to assess whether there is a different share price reaction just before and immediately after the announcement of takeover.

It should be noted that the models above are estimated using three alternative indexes of Athens Exchange standing as proxies for the market return, namely the Banking 
Sector Index, the General Index of Athens Exchange and the Large Cap Index, which includes the 20 largest entities of the Greek stock exchange in terms of capitalization (Alpha Bank is one of those 20 firms).

\subsubsection{Empirical evidence}

Before analyzing the abnormal returns obtained by estimating the models (1) to (4), Table 2 provides some information on the descriptive and trading statistics over the four periods concerned. In particular, Table 2 provides information on the average daily return and the risk of Alpha Bank share, the intraday volatility calculated in percentage terms as the fraction of highest minus lowest price on day $t$ to the closing price on the same day. Similar information is provided for the three market indexes used too. Finally, the table includes the average terms of daily volume (in number of traded shares), the average daily turnover (in euros), and the number of the average daily transactions on Alpha Bank share.

Over the first estimation period (i.e. 300 days before the announcement of takeover to 60 days before the announcement), Table 2 shows that the Alpha Bank share was achieving an average daily return of $-0.019 \%$. This was better than the corresponding market returns. On the other hand, the share of Alpha Bank was significantly riskier than the market proxies as inferred by the estimates of both the risk and intraday volatility. Finally, the trading activity of Alpha Bank share over the first estimation period was substantial (from the perspective of the Greek stock exchange) with an average of about 4.5 shares traded each day via the execution of 2,311 transactions amounting to approximately $€ 5.4$ million.

During the event window (i.e. 60 days before and 60 days after the announcement), the average daily return of Alpha Bank share is equal to $0.380 \%$ being in line with the return of the General Index of Athens Exchange but superior to the returns of the Banking Sector Index and the Large Cap Index. The increase in average return of Alpha Bank could be related to the announcement of Emporiki Bank's takeover or could be the just a result of the upward path of Athens Exchange evidenced by the increase in the value of General Index. However, the superiority of Alpha Bank over the two other market indexes examined gives some support to the idea that the announcement may have positively affected the pricing of Alpha Bank's share and is indicative of a positive price reaction from the market to the announcement.

Furthermore, during the event period Alpha Bank remains riskier than the market benchmarks. On the other hand, Table 2 reports a relative drop in trading activity as assessed by the decreased number of shares traded on average over the event window and the average number of transactions. The average turnover however is 
slightly higher than that prior to the event period obviously as a result of the increased value of Alpha Bank share.

When it comes to the 60-day period before the announcement, the daily return of Alpha Bank was remarkable compared to those of the indexes. More specifically, the average return is equal to $1.100 \%$ being significantly higher than the respective return of Banking Sector Index, General Index and Large Cap Index. This pattern could be indicative of the fact that the market has discounted the possible implications for Alpha Bank deriving from the possible takeover of Emporiki Bank. Furthermore, Alpha Bank share remains riskier than the indexes. On the question of trading activity, Alpha Bank share seems to be less tradable over the 60-day period before the announcement. This is evidenced by the decreased volume, turnover and number of transactions compared to the previous periods assessed.

Finally, during the 60-day period after the announcement of takeover, the average daily return of Alpha Bank is negative being lower than the returns of the General and Large Cap Index but better than that of the Banking Sector Index. This is in line with a similar negative pattern in post-announcement returns found by Martynova and Renneboog (2006) in the case of European mergers and acqusitions over the period 1993-2001. The main inference that can be drawn by comparing the return of Alpha Bank share to the returns of benchmarks is that Alpha Bank was in a better position than the other Greek banks included in the Banking Index possibly as a result of the announcement of takeover. On the other hand, banking sector as a whole was in trouble over the 60-day period after the announcement (ending on 14 January 2013) possibly due to the standing financial and fiscal problems faced by the Greek economy. The rise in the value of General and the Large Cap Indexes during that period must have been supported by the non-financial entities comprising the index.

When it comes to tradability immediately after the announcement, Table 2 shows an increase in such an activity expressed in all the alternative measurements of trading activity. Given the decrease in share price of Alpha Bank, the increased tradability may be mainly accounted for by redemption of shares rather than new purchases. However, we have no relevant data available that allows us to reach a firm conclusion in this respect.

Overall, given that the takeover of Emporiki Bank by Alpha Bank was a friendly one, my analysis lies within the framework of the studies of Goergen and Renneboog (2004), Gregory (1997), Franks and Mayer (1996) and Servaes (1991) which have shown that the announcement of friendly takeovers results in higher returns for the bidding firms. The analysis of unadjusted raw returns of Alpha Bank share can be considered to provide some support to the findings of the above studies. 
Table 2. Trading statistics

Panel A: Estimation Period 1

\begin{tabular}{lcccccc}
\hline & Return (\%) & Risk (\%) & $\begin{array}{c}\text { Intraday } \\
\text { volatility (\%) }\end{array}$ & $\begin{array}{c}\text { Volume } \\
\text { (in shares) }\end{array}$ & $\begin{array}{c}\text { Turnover } \\
\text { (in Euros) }\end{array}$ & $\begin{array}{c}\text { No of } \\
\text { transactions }\end{array}$ \\
\cline { 2 - 7 } Alpha Bank & -0.019 & 8.749 & 10.135 & $4,466,483$ & $5,371,094.70$ & 2,311 \\
\hline Banking Index & -0.348 & 6.254 & 7.657 & - & - & - \\
\hline General Index & -0.188 & 2.800 & 3.504 & - & - & - \\
\hline Large Cap Index & -0.242 & 3.473 & 4.395 & - & - & - \\
\hline
\end{tabular}

Panel B: Estimation Period 2

\begin{tabular}{lcccccc}
\hline & Return (\%) & Risk (\%) & $\begin{array}{c}\text { Intraday } \\
\text { volatility (\%) }\end{array}$ & $\begin{array}{c}\text { Volume } \\
\text { (in shares) }\end{array}$ & $\begin{array}{c}\text { Turnover } \\
\text { (in Euros) }\end{array}$ & $\begin{array}{c}\text { No of } \\
\text { transactions }\end{array}$ \\
\cline { 2 - 7 } Alpha Bank & 0.380 & 6.231 & 7.513 & $3,434,480$ & $5,704,457.47$ & 1,913 \\
\hline Banking Index & 0.188 & 5.439 & 6.756 & - & - & - \\
\hline General Index & 0.378 & 2.147 & 2.851 & - & - & - \\
\hline Large Cap Index & 0.339 & 2.721 & 3.538 & - & - & - \\
\hline
\end{tabular}

Panel C: Estimation Period 3

\begin{tabular}{lcccccc}
\hline & Return (\%) & Risk (\%) & $\begin{array}{c}\text { Intraday } \\
\text { volatility (\%) }\end{array}$ & $\begin{array}{c}\text { Volume } \\
\text { (in shares) }\end{array}$ & $\begin{array}{c}\text { Turnover } \\
\text { (in Euros) }\end{array}$ & $\begin{array}{c}\text { No of } \\
\text { transactions }\end{array}$ \\
\cline { 2 - 7 } Alpha Bank & 1.100 & 4.986 & 5.998 & $2,884,674$ & $4,501,529.35$ & 1,534 \\
\hline Banking Index & 0.918 & 4.440 & 5.582 & - & - & - \\
\hline General Index & 0.492 & 2.200 & 2.747 & - & - & - \\
\hline Large Cap Index & 0.527 & 2.663 & 3.268 & - & - & - \\
\hline
\end{tabular}

Panel D: Estimation Period 4

\begin{tabular}{lcccccc}
\hline & Return (\%) & Risk (\%) & $\begin{array}{c}\text { Intraday } \\
\text { volatility (\%) }\end{array}$ & $\begin{array}{c}\text { Volume } \\
\text { (in shares) }\end{array}$ & $\begin{array}{c}\text { Turnover } \\
\text { (in Euros) }\end{array}$ & $\begin{array}{c}\text { No of } \\
\text { transactions }\end{array}$ \\
\cline { 2 - 7 } Alpha Bank & -0.405 & 7.258 & 9.062 & $3,971,928$ & $6,863,253.27$ & 2,286 \\
\hline Banking Index & -0.576 & 6.264 & 7.973 & - & - & - \\
\hline General Index & 0.240 & 2.113 & 2.956 & - & - & - \\
\hline Large Cap Index & 0.125 & 2.801 & 3.816 & - & - & - \\
\hline
\end{tabular}

Estimation Period 1: 300 days before the announcement of Emporiki Bank's Takeover on 16 October 2012 to 60 days before the announcement.

Estimation Period 2: 60 days before and 60 days after the announcement of takeover.

Estimation Period 3: 60 days before the announcement of takeover.

Estimation Period 4: 60 days after the announcement of takeover.

Table 3 provides the calculations of abnormal returns of Alpha Bank share compared to the three market indexes over the four investment windows concerned. The table presents the computations of abnormal returns and the $t$-statistics on the statistical significance of the figures along with the alpha and beta coefficients obtained by the estimation of the market and Dimson (1979) models.

The main element deriving from the calculations is that no abnormal returns are achieved by the Alpha Bank share as a result of to the announcement of Emporiki Bank's acquisition. All the individual abnormal return figures calculated are essentially 
nil since they lack any statistical significance. The results are relatively in line with the findings of Martynova and Renneboog (2006), who report modest abnormal returns for the bidding companies amounting to just $0.5 \%$.

Table 3. Abnormal returns of Alpha Bank share

Panel A: Estimation Period 1

\begin{tabular}{lcccccc}
\hline & \multicolumn{3}{c}{ Market model } & \multicolumn{3}{c}{ Dimson model } \\
\cline { 2 - 7 } & alpha & beta & Abnormal return & alpha & beta & Abnormal return \\
\hline Banking Index & $0.463^{\mathrm{b}}$ & $1.296^{\mathrm{a}}$ & -0.032 & $0.520^{\mathrm{b}}$ & 1.423 & -0.044 \\
\hline$(t$-test $)$ & $(2.164)$ & $(37.896)$ & $(-0.148)$ & $(2.403)$ & - & $(-0.203)$ \\
\hline General Index & 0.562 & $2.418^{\mathrm{a}}$ & -0.128 & 0.602 & 2.642 & -0.126 \\
\hline$(t$-test) & $(1.323)$ & $(19.391)$ & $(-0.360)$ & $(1.372)$ & - & $(-0.352)$ \\
\hline Large Cap Index & $0.615^{\mathrm{b}}$ & $2.126^{\mathrm{a}}$ & -0.120 & $0.652^{\mathrm{c}}$ & 2.351 & -0.103 \\
\hline$(t$-test) & $(2.016)$ & $(24.255)$ & $(-0.397)$ & $(1.816)$ & - & $(-0.335)$ \\
\hline
\end{tabular}

Panel B: Estimation Period 2

\begin{tabular}{lcccccc}
\hline & \multicolumn{3}{c}{ Market model } & \multicolumn{3}{c}{ Dimson model } \\
\cline { 2 - 7 } & alpha & beta & Abnormal return & alpha & beta & Abnormal return \\
\hline Banking Index & 0.183 & $1.062^{\mathrm{a}}$ & -0.003 & 0.237 & 0.958 & -0.037 \\
\hline$(t$-test) & $(0.874)$ & $(19.777)$ & $(-0.013)$ & $(1.172)$ & - & $(-0.171)$ \\
\hline General Index & -0.432 & $2.301^{\mathrm{a}}$ & -0.057 & -0.363 & 2.122 & -0.058 \\
\hline$(t$-test) & $(-1.231)$ & $(14.194)$ & $(-0.164)$ & $(-1.014)$ & - & $(-0.168)$ \\
\hline Large Cap Index & -0.241 & $1.956^{\mathrm{a}}$ & -0.042 & -0.185 & 1.823 & -0.053 \\
\hline$(t$-test) & $(-0.811)$ & $(17.941)$ & $(-0.142)$ & $(-0.625)$ & - & $(-0.178)$ \\
\hline
\end{tabular}

Panel C: Estimation Period 3

\begin{tabular}{lcccccc}
\hline & \multicolumn{3}{c}{ Market model } & \multicolumn{3}{c}{ Dimson model } \\
\cline { 2 - 7 } & alpha & beta & Abnormal return & alpha & beta & Abnormal return \\
\hline Banking Index & 0.200 & $0.980^{\mathrm{a}}$ & 0.000 & 0.403 & 0.729 & 0.028 \\
\hline$(t$-test) & $(0.678)$ & 10.383 & $(0.001)$ & $(1.466)$ & - & $(0.081)$ \\
\hline General Index & 0.248 & $1.816^{\mathrm{a}}$ & -0.042 & 0.286 & 1.426 & 0.112 \\
\hline$(t$-test) & $(0.626)$ & 10.208 & $(-0.108)$ & $(0.672)$ & - & $(0.281)$ \\
\hline Large Cap Index & 0.294 & $1.588^{\mathrm{a}}$ & -0.030 & 0.316 & 1.300 & 0.100 \\
\hline$(t$-test) & $(0.842)$ & 12.203 & $(-0.088)$ & $(0.858)$ & - & $(0.281)$ \\
\hline
\end{tabular}

Panel D: Estimation Period 4

\begin{tabular}{lrrrrrr}
\hline & \multicolumn{3}{c}{ Market model } & \multicolumn{3}{c}{ Dimson model } \\
\cline { 2 - 7 } & alpha & beta & Abnormal return & alpha & beta & Abnormal return \\
\hline Banking Index & 0.235 & $1.104^{\mathrm{a}}$ & -0.004 & 0.329 & 1.078 & -0.113 \\
\hline$(t$-test) & $(0.763)$ & $(16.880)$ & $(-0.013)$ & $(1.040)$ & - & $(-0.394)$ \\
\hline General Index & $-1.010^{\circ}$ & $2.798^{\mathrm{a}}$ & -0.066 & -0.790 & 2.412 & -0.193 \\
\hline$(t$-test) & $(-1.834)$ & $(10.699)$ & $(-0.121)$ & $(-1.395)$ & - & $(-0.349)$ \\
\hline Large Cap Index & -0.642 & $2.268^{\mathrm{a}}$ & -0.047 & -0.456 & 2.062 & -0.207 \\
\hline$(t$-test) & $(-1.405)$ & $(13.782)$ & $(-0.103)$ & $(-0.991)$ & - & $(-0.450)$ \\
\hline
\end{tabular}

Abnormal return $=$ Realized return - Benchmark return

Benchmark return $=a+b^{*}$ (Market return)

Estimation Period 1: 300 days before the announcement of Emporiki Bank's Takeover on 16 October 2012 to 60 days before the announcement.

Estimation Period 2: 60 days before and 60 days after the announcement of takeover.

Estimation Period 3: 60 days before the announcement of takeover.

Estimation Period 4: 60 days after the announcement of takeover.

${ }^{a}$ statistically significant at the $1 \%$ level; ${ }^{\text {b }}$ statistically significant at the $5 \%$ level; ${ }^{\text {c }}$ statistically significant at the $10 \%$ level. 


\section{Conclusion}

Competition among business corporations for the dominance of the market and profit maximization leads companies to involve in mergers with other entities or the acquisition of other firms. The issue of mergers and acquisitions is the subject of the current paper. The focus of the study is on the description of the several types of mergers between firms, the main incentives behind this kind of corporate action, and the analysis of the various counterincentives and obstacles that hinder such deals and quite often result in the failure of these endeavors. Significant attention is also paid to the financing options for mergers and acquisitions. A brief historical analysis of the major mergers and acquisitions waves along with the examination of recent trends in the corporate and banking sectors are provided. Afterwards, the recent wave of acquisitions among the Greek banks is discussed focusing on the takeover of Emporiki Bank by Alpha Bank and the share price reaction to the announcement of the takeover.

With respect to types, it should be noted that there are a lot of merger and acquisition schemes. Probably, the most significant element regarding the types is that mergers and acquisitions are not always friendly, namely the both parties of a deal do not always voluntarily consent to the transaction taking place.

On the question of incentives and motivations behind these corporate deals, the main inference is that companies adopting such policies believe that purchasing or merging with other companies can contribute to the improvement of their financial performance and the enhancement of their strength whereas it can also help mitigate competition from other players, possibly resulting in the control of the overall market and an increase in revenues and profits.

When it comes to the counterincentives that frequently result in the failure of such deals, they first relate to fears of the target entity's staff that they might be deprived of their benefits or even lose their jobs. Another source of failure stems from the cultural differences between the two firms. The low frequency and/or low quality of the communication of the expected benefits to the target company's staff can also contribute to a merger or acquisition deal being unsuccessful. The lack of a suitable strategic plan based on rational and prudent expectations about the synergies, economies of scale and the profits to be made provides an inaccurate view of the possibilities of the initiative and may lead to the failure of the entire venture. Finally, issues regarding the techniques applied for the evaluation of the target firm, which might lead to unduly high prices being paid, along with possible unfavorable economic conditions and legal and institutional framework might lead to a merger or acquisition failing to achieve its aims and goals. 
Finally, as far as the financing of mergers and acquisitions is concerned, there are several possible approaches, the two most significant of which are payment in cash or for the acquiring company to issue stocks and transfer them to the shareholders of the target entity. Overall, there are some general factors that must be considered when deciding on the payment method. These factors relate to the possible existence of other offers for the target firm, the size of the offers and their payment method, which may be crucial in order for the target company to decide on which bid to go for, taxation, and the possible effects on the buyer's capital structure. A last element needing to be taken into account in the financing of an acquisition is that the payment method can signal value to the other party. In particular, the buyer's willingness to offer stock for the payment may result in the directors of the target entity assuming that the buyer believes that its stocks are overvalued. On the contrary, if cash is offered, it may seem that the bidder believes that its stocks are undervalued.

With respect to the trends in mergers and acquisitions, historically speaking, the relevant waves in the United States relate to high growth rates in the economy after the end of wars or as a result of major technological innovations as well as the favoritism displayed by the American governments on an enduring and consistent basis. On the other hand, in Europe, mergers and acquisitions have been positively affected by the creation of the Unified European Market, deregulation and global competition. The reform of credit and banking systems in Europe also created opportunities for profitable consolidations as did the collapse of the socialist regimes in Eastern Europe and the consequent denationalization of state firms and business sectors. In Asia, mergers and acquisitions activity has been less strong and the majority of Asian countries have not been very active in this field.

Finally, the paper highlights the fact that the Greek banking sector recently displayed intense activity in the field of acquisitions. This was mainly triggered by the recapitalization needs of Greek banks resulting from the huge losses written onto their balance sheets due to the haircut of the Greek sovereign bonds. As shown, Piraeus Bank was the most active and possibly the most benefited bank out of the four systemic Greek banks significantly increasing its market share and strengthening its presence in the Greek banking system.

With respect to the case study examined in this paper- the acquisition of Emporiki Bank by Alpha Bank-, the analysis has revealed that material benefits are expected to materialize from this transaction over a three-year interval in terms of synergies, cost savings and increased business and turnover. When it comes to the impact on the share price of Alpha Bank exerted by the announcement of takeover on 16 October 2012, the analysis provided some evidence of a positive impact on the value (raw returns) of Alpha Bank share around a relevant event period of 60 days before and after the 
announcement. However, statistically significant abnormal returns compared to the expected returns calculated using suitable models were not gained over that period.

\section{References}

Agrawal, A. and Mandelker, G. (1987). Managerial Incentives and Corporate Investment and Financing Decisions, Journal of Finance, 42(4), pp. 823-37.

Andrade, G., Mitchell, M. and Stafford, E. (2001). New Evidence and Perspectives on Mergers?, Journal of Economic Perspectives, 15(2), pp. 103-120.

Basmah, A.Q. and Rahatullah (2014). Financial Synergies in Mergers and Adquisitions. Evidence from Saudi Arabia, AESTIMATIO, the IEB International Journal of Finance, 9, pp. 9-25.

Bharadwaj, A. and Shivdasani, A. (2003). Valuation Effects of Bank Financing in Acquisitions, Journal of Financial Economics, 67, pp. 113-148.

Berger, A.N. and Humphrey, D.B. (1991). The Dominance of Inefficiencies over Scale and Product Mix Economies in Banking, Journal of Monetary Economics, 28(2), pp. 117-48.

Bhide, A. (1990). Reversing Corporate Diversification, Journal of Applied Corporate Finance, 3, pp. 70-81.

Borio, C. and Tsatsaronis, K. (2005). Accounting, Prudential Regulation and Financial Stability: Elements of a Synthesis, Bank for International Settlements, BIS Working Papers No 180, (available at www.bis.org).

Comment, R. and Jarrell, G. (1995). Corporate Focus and Stock Returns, Journal of Financial Economics, 37, pp. 67-88.

Conn, R., Cosh, A.D., Guest, P.M. and Hughes, A. (2005). The Impact on U.K. Acquirers of Domestic, Cross-Border, Public and Private Acquisitions, Journal of Business Finance and Accounting, 32, pp. 815-870.

Danbolt, J. (2004). Target Company Cross-border Effects in Acquisitions into the UK, European Financial Management, 10, pp. 83-108.

Dewenter, K. (1995). Does the Market React Differently to Domestic and Foreign Takeover Announcements? Evidence from the US Chemical and Retail Industries, Journal of Financial Economics, 37, pp. 421-441.

Dimson E. (1979). Risk Measurement when Shares are Subject to Infrequent Trading, Journal of Financial Economics, 7, pp. 197-226.

Faccio, M. and Masulis, R.W. (2005). The Choice of Payment Method in European Mergers and Acquisitions, Journal of Finance, 60, pp. 1345-1388.

Franks, J., Harris, R. and Titman, S. (1991). The Postmerger Share-Price Performance of Acquiring Firms, Journal of Financial Economics, 29, pp. 81-96.

Franks, J. and Mayer, C. (1996). Hostile Takeovers and the Correction of Managerial Failure, Journal of Financial Economics, 40, pp. 163-181.

Gang Bi, X. and Gregory A. (2010). Stock Market Driven Acquisitions versus the Q-theory of Takeover- The UK Evidence, Centre for Finance and Investment. Discussion Paper 08/05.

Goergen, M. and Renneboog, L. (2004). Shareholder Wealth Effects of European Domestic and Cross Border Takeover Bids, European Financial Management, 10, pp. 9-45. 
Gregory, A. (1997). An Examination of the Long Run Performance of UK Acquiring Firms, Journal of Business Finance and Accounting, 24, pp. 971-1002.

Harford, J., Klasa, S. and Walcott, N. (2009). Do firms Have Leverage Targets? Evidence from Acquisitions, Journal of Financial Economics, 93, pp. 1-14.

Hasbrouck, J. (1985). The Characteristics of Takeover Targets: Q and Other Measures, Journal of Banking and Finance, 9, pp. 351-362.

Healy, P., Palepu, K.G. and Ruback, R.S. (1997). Which takeovers are Profitable: Strategic or Financial?, Sloan Management Review, 38, pp. 45-57

Higgins, R. and Schall, L. (1975). Corporate Bankruptcy and Conglomerate Merger, Journal of Finance, 30, pp. 93-113. Karampatsas, N., Petmezas, D. and Travlos, N.G. (2013). Credit Ratings and the Choice of Payment Method in Mergers and Acquisitions, Annual Meeting of European Financial Management Association, Reading, UK.

Lewellen, W. (1971). A Pure Financial Rationale for the Conglomerate Merger, Journal of Finance, 26, pp. 521-545.

Martynova, M. and Renneboog, L. (2006). Mergers and Acquisitions in Europe, European Corporate Governance Institute, Working Paper.

Moeller, S., Schlingemann, F. and Stulz, R. (2004). Firm Size and the Gains from Acquisitions, Journal of Financial Economics, 73, pp. 201-228.

Mitchell, M.L. and Lehn, K. (1990). Do Bad Bidders Become Good Targets?, Journal of Political Economy, 98, pp. 372-398.

Nelson, R. (1959). Merger Movements in the American Industry, NBER, New York.

Palepu, K.G. (1986). Predicting Takeover Targets: A Methodological and Empirical Analysis, Journal of Accounting and Economics, 8, pp. 3-35.

Rau, P.R. and Vermaelen, T. (1998). Glamour, Value and the Post-acquisition Performance of Acquiring Firms, Journal of Financial Economics, 49, pp. 223-253.

Ravenscraft, D.J. and Scherer, F.M. (1989). The Profitability of Mergers, International Journal of Industrial Organization, 7, pp. 101-116.

Shleifer, A. and Vishny, R.W. (2003). Stock Market Driven Acquisitions, Journal of Financial Economics, 70, pp. 295-311.

Scholes, M. and Wolfson, M. (1990). The Effects of Changes in Tax Laws on Corporate Reorganization Activity, Journal of Business, 63(1), pp. 141-164.

Servaes, H. (1991). Tobin's Q and the Gains from Takeovers, Journal of Finance, 46(1), pp. 409-419.

Servaes, H. (1996). The Value of Diversification During the Conglomerate Merger Wave, Journal of Finance, 51(4), pp. 1201-1226.

Uysal, V.B. (2011). Deviation from the Target Capital Structure and Acquisition Choices, Journal of Financial Economics, 102, pp. 602-620.

Wansley, J., Lane, W. and Yang, H. (1983). Shareholder Returns to US Acquired Firms and Domestic Acquisitions, Journal of Business Finance and Accounting, 10, pp. 647-656. 